\title{
Między exodusem a emancypacją
}

W kwietniu 2009 roku powstało we Wrocławiu Miasteczko Edukacji Krytycznej - forma happeningu będąca wyrazem sprzeciwu wobec postępujących zmian w systemie szkolnictwa wyższego, związanych przede wszystkim z wdrażaniem postanowień Proces Bolońskiego. Performerzy, wcielając się w rolę „rzeźników edukacji”, symbolizujących pomysłodawców krytykowanych zmian, ironicznie i sarkastycznie prezentowali „dobrodziejstwa”, jakie niesie ze sobą Proces Boloński. Miasteczko Edukacji Krytycznej stanowi symboliczny początek oporu środowiska wrocławskich młodych akademików i akademiczek wobec przemian zachodzących na polskich uniwersytetach. Kolejnym krokiem była organizacja konferencji poświęconej tej problematyce. Wydana niedawno książka Uniwersytet i emancypacja: wiedza jako dziatanie polityczne - dziatanie polityczne jako wiedza, stanowi jej pokłosie.

W porównaniu z happeningiem, recenzowana książka, oprócz krytyki, stanowi również (a może przede wszystkim) próbę sformułowania pozytywnego projektu zmian. Redaktorki - Marta Trawińska i Małgorzata Maciejewska - punkt wyjścia dla podejmowanych w pracy rozważań widzą w konstatacji istnienia wyraźnego napięcia między dwoma alternatywnymi wizjami uniwersytetu (niemalże Weberowskimi) ${ }^{1}$.

1 M. Weber, Nauka jako zawód i powotanie, tłum. P. Dybel, [w:] tegoż, Polityka jako zawód i powotanie, Kraków 1998, s. 111-140. 
Pomiędzy uniwersytetem funkcjonującym jako efektywne ekonomicznie, kapitalistyczne przedsiębiorstwo, a uniwersytetem w „starym stylu”2, coraz częściej określanym w debatach prasowych mianem „feudalnego".

Autorzy i autorki Uniwersytetu i emancypacji podważają to zideologizowane utożsamienie modernizacji i neoliberalizacji, proponując w zamian poszukiwanie innej, emancypacyjnej drogi, którą mógłby

Zmieniła się nie tylko funkcja, ale także proces

tworzenia wiedzy -

w okresie późnej

nowoczesności logika

fabryki wyszła poza nią samą, obejmując także uniwersytet kroczyć współczesny uniwersytet. $Z$ tego też wynika wewnętrzny podział książki na dwie części. Pierwsza z nich to diagnoza sytuacji (Uniwersytet $w$ logice rynkowej i niebezpieczny kognitariat), druga zaś poświęcona jest omówieniu rysujących się na horyzoncie przyczółków emancypacji (Produkcja wiedzy usytuowanej).

\section{Oblicza emancypacji}

Nieliczni, którzy wciąż jeszcze wierzą w wizję „nauki uprawianej z boskiego punktu widzenia"s, nie znajdą tutaj dla siebie zbyt wiele. Wedle autorek i redaktorek książki, wytwarzanie wiedzy jest zawsze usytuowane i uwikłane politycznie. Na pytania, dla kogo produkowana jest wiedza na dzisiejszych polskich uniwersytetach i komu służy, odpowiadają one wprost: wyznaczanym przez MNiSW priorytetem współczesnej akademii jest służba rozwojowi gospodarczemu, zaś w ramach tej wizji naukom społecznym przyznano zadanie badania „drgań rynku” i dbania o marketing. Zmieniła się nie tylko funkcja, ale także proces tworzenia wiedzy - w okresie późnej nowoczesności logika fabryki wyszła poza nią samą ${ }^{4}$, obejmując także uniwersytet.

Temat ten podejmuje bezpośrednio Tomasz Skoczylas w artykule opisującym zrestrukturyzowane szkolnictwo wyższe na Zachodzie, będące przecież dziś utopijnym punktem odniesienia dla polskich reformatorów. Dyskurs konkurencyjności, zrodzony wśród amerykańskich elit w okresie zapaści finansowej tamtejszych akademii, przybrał formę „doktryny szoku”. Antidotum na kryzys miały być biznesowe techniki zarządzania oraz powiększenia uczelnianej administracji, czego rewer-

\section{Tamże.}

3 M. Maciejewska, M. Trawińska, Wstęp, [w:] Uniwersytet i emancypacja: wiedza jako dziatanie polityczne - dziatanie polityczne jako wiedza, red. M. Maciejewska, M. Trawińska, Wrocław 2012, s. 12.

4 Zob. rozdział The Social Factory: Machines, Work, Control, [w:] N. Thoburn, Deleuze, Marx and Politics, London 2003, s. 69-102. 
sem stała się proletaryzacja pracowników naukowych. Proces ten nie pociąga za sobą tylko utraty symbolicznego statusu „wysoko wykwalifikowanego specjalisty", ale przede wszystkim utratę autonomii, kontroli nad własną pracą (czyli alienację). Utrata bezpieczeństwa i stabilności zawodowej, a także postępująca komercjalizacja nauczania, prezentowana jest w tym modelu jako jedyna racjonalna alternatywa.

Stosowany w odniesieniu do szkolnictwa wyższego stricte ekonomiczny język przeniknął do Polski i jest używany w ewaluacji wyników pracy naukowej. Sporej części naukowego establishmentu oraz politykom towarzyszy chęć powiązania wszystkich dziedzin nauki z gospodarką rynkową; rezultaty badań mają się wymiernie przekładać na efekt rynkowy. Nadwiślańscy neoliberałowie zdają się jednak nie dostrzegać, że zapotrzebowanie polskiej półperyferyjnej gospodarki, głównie małych i średnich firm, wiąże się nie tyle z innowacjami technologicznymi, ile z popytem na sprofilowanych pracowników niższego szczebla, takich jak m.in. telemarketer i technik prac biurowych ${ }^{5}$.

W opozycji do języka neoliberalnego obiegowo funkcjonuje opór jawnie konserwatywny, podszyty elitaryzmem oraz wiarą w możliwość politycznej niezależności uniwersytetu. Tej wiary, jak też samej osi sporu neoliberalizm - feudalizm akademicki nie podzielają autorzy dwóch kolejnych tekstów tekstów (Piotr Antoniewicz, Piotr Kowzan, Dominik Krzymiński) ${ }^{6}$, którzy skupiają się na poszukiwaniu konstruktywnej strategii dla doktoranckich ruchów oporu. Ich diagnoza jest polityczna w tym sensie, że porusza zagadnienie możliwych instytucjonalizacji świadomości klasowej. Doktoranci, których liczba z roku na rok rośnie ${ }^{7}$, wręcz modelowo wpisują się w szeregi prekariatu. Słabość tego pojęcia, na którą zwracają uwagę jego krytycy, jest paradoksalnie w tym wypadku jego największą siłą. Grupy, które wchodzą w skład kategorii prekariatu, są zróżnicowane i nie sprowadzają się wyłącznie do pracowników nauki, ale obejmują też zawody pozauniwersyteckie innego typu. O ile jednak u Antoniewicza kwestia ta przybiera postać teoretyczną, a emancypacyjny uniwersytet jest definiowany jako „demokratyczna i kolektywna praktyka, która jest formą (re)produkcji świadomości prekariatu", o tyle u Kowzana i Krzymińskiego mamy do czynienia z opisem realnej próby wykorzystania instytucji samorządu doktoranc-

5 Ministerstwo Pracy i Polityki Społecznej, Zawody deficytowe i nadwyżkowe w I pótroczu 2012 roku, Warszawa 2012, s. 14.

6 P. Antoniewicz, Exodus z fabryki wiedzy; P. Kowzan, D. Krzymiński, Pomiędzy alienacja a emancypacja, [w:] Uniwersytet i emancypacja...

7 Szkoty wyższe i ich finanse 2011, Warszawa 2012, s. 37. 
kiego Uniwersytetu Gdańskiego w celu uzyskania pewnych zabezpieczeń, a dokładniej - uzyskania stypendiów. Przeprowadzony przez nich opis konfliktu w ramach Uczelnianej Rady Doktorantów, na tle niespełnionych obietnic poczynionych przez władze wydziału doktorantom pierwszego roku, jest być może najważniejszą częścią Uniwersytetu i emancypacji. Przedstawia podziały między wydziałami płacącymi i niepłacącymi stypendia, stereotypy na temat poszczególnych dziedzin naukowych i ich przedstawicieli, a także zróżnicowanie poglądów na konkretne problemy szkolnictwa wyższego.

Pierwszym obliczem emancypacji jest przezwyciężenie alienacji samych pracowników naukowych, także tych, którzy - jak doktoranci - nie posiadają formalnie pracowniczego statusu, choć ich aktywność w sensie ekonomicznym należy nazwać nieopłacaną pracą, zaś samych doktorantów elastyczną i tanią siłą roboczą. Misja uniwersytetu emancypacyjnego na tym jednak się nie kończy - jednym z podstawowych celów redaktorek oraz autorek i autorów jest przeciwstawienie się abs-

Pierwszym obliczem emancypacji jest przezwyciężenie alienacji samych

pracowników naukowych, także tych, którzy - jak doktoranci - nie posiadają formalnie pracowniczego statusu,

choć ich aktywność w sensie ekonomicznym

należy nazwać nieopłacaną pracą, zaś samych doktorantów elastyczną i tanią siłą roboczą trakcyjnie rozumianej autonomii akademii. Kapitalistyczna logika i stosunki pracy objęły całe społeczeństwo. Odpowiedzią na ten proces są próby konserwatywnej obrony uniwersytetu-bastionu. Taka strategia jest jednak błędna nie tylko ze względu na niezrozumienie zachodzących przemian, lecz przede wszystkim z powodu swojej nieskuteczności i braku perspektyw dla przyszłego owocnego funkcjonowania tak pomyślanego uniwersytetu. Wiedza nie służy samej sobie, gdyż jej produkcja odbywa się zawsze dla kogoś. Analizując zagadnienia procesu produkcji i rozpowszechniania wiedzy, możemy dostrzec istotne zróżnicowania społeczne, a wobec tego projekty zmian funkcji uniwersytetu powinny być zorientowane na egalitarną dystrybucję wiedzy. Doprowadzić by to mogło nie tylko do zmian strukturalnych, np. w rekrutacji na poszczególne stopnie studiów, lecz również do współpracy akademickich ruchów społecznych z ruchami pracowniczymi poza uczelnią.

Kwestia granicy uniwersytet/rzeczywistość pozauniwersytecka oraz problem zróżnicowań społecznych na uczelniach podejmowane są w tekstach Moniki Popow i Małgorzaty Zielińskiej, dotyczących zaburzonych wersji emancypacji. Popow opisuje kierunki sfeminizowane, głównie dotyczące opieki społecznej, które przygotowują do najniżej opłacanych prac w sektorze usług. Badaczka stawia pytanie, czy współczesny polski uniwersytet rzeczywiście emancypuje kobiety pod względem intelektualnym, finansowym i kulturowym. W jej oczach mamy do czynienia z „emancypacją naiwną”, która pełni funkcję genderowej reprodukcji, wtłaczania w role społeczne i prace w gospodarce opierające się na tzw. miękkich kompetencjach społecznych (opieka, wycho- 
wanie, leczenie), przypisywanych kulturowo kobietom. Pozytywną stroną tak rozumianej „naiwnej emancypacji” jest transmisja wiedzy, także tej o potencjale krytycznym. Zielińska analizuje również „emancypację ironiczną”, czyli możliwość pracy zagranicą poniżej kwalifikacji (która ma zwalniać z panującej w Polsce presji społecznej na wykonywanie przez absolwentów pracy umysłowej). Obie emancypacje mają charakter patologiczny - oznaczają podporządkowanie kodom kulturowym albo ucieczkę.

\section{Emancypacja metodologiczna}

Dział Wiedza usytuowana jest niejako przedłużeniem dywagacji o relacjach władzy w obrębie świata akademickiego. Tym razem przedmiot analizy stanowi władza decydowania o ,środkach produkcji” wiedzy, czyli doboru metodologii, oraz ich usytuowaniu na polu pozamerytorycznych założeń i wartości. W ogólniejszym sensie, zbliżonym do perspektywy socjologii publicznej, chodzi o moc uznawania czegoś za wiedzę naukową. Ten dział skupia się na postulowanej przez autorki/ autorów funkcji uniwersytetu, w szczególności nauk społecznych.

Agnieszka Kowalczyk porusza zagadnienie „obietnicy” nauk społecznych, tematyzowanej w pracach klasyków socjologii, takich jak Max Weber czy Charles Wright Mills. Obietnica polega na poszerzaniu wyobraźni społecznej, przekazaniu wiedzy na temat rzeczywistości społecznej i jej mechanizmów słabym oraz uzmysłowieniu skutków władzy potężnym. Stawką jest pomyślenie alternatyw w polu samej praktyki badawczej. Autorka skłania się tutaj ku tzw. militant research, współbadaniom, które wywodzą się z operaistycznych nurtów marksizmu i polegają na odejściu od produkcji intelektualnej opartej na podziale badacz/obiekt badany na rzecz "produktywnej kooperacji” oraz wzajemnego przekształcania podmiotów wytwarzania wiedzy. W takim ujęciu wiedza ma ostrze krytyczne nie tylko na polu teorii, ale również aktywizmu społecznego. Jest nie tylko próbą zniesienia granic pracy naukowej, ale także poszerzenia puli podmiotów, dla których wiedza jest wytwarzana.

Artykuł Anny Szołuchy przedstawia zbliżony do współbadań projekt Participatory Action Research. W ramach tego paradygmatu fazy badania i działania są równoważne. Jest to metoda nie tylko wymagająca (jako że natychmiastowo sprawdza teorię w praktyce - w przeciwieństwie od wiedzy wytworzonej w sposób tradycyjny), ale mająca też na celu aplikację tej wiedzy. Znosi także dychotomię aktywizm/teorety- 
zowanie, która zazwyczaj wykorzystywana jest do dyskredytacji jednej lub drugiej aktywności.

Problemem dla produkcji i rozpowszechniania wiedzy są również struktury prawne. Jak wykazał w swoim tekście Grzegorz Stunża, wiedza wytworzona za publiczne środki podlega prywatyzacji, patentowaniu, ograniczaniu możliwości wykorzystania przez szersze grupy społeczne. Społeczeństwo „oparte na wiedzy”, w którym wiedza przekształcana jest w towar, reprodukuje strukturę klasową. Emancypacja na polu nowych praktyk badawczych daje możliwości wykorzystania wiedzy dla zmiany społecznej.

\section{Kolonizacja pojedynczości}

Kolonizację menadżerską prowadzi się w imię walki z biurokracją, lecz środkiem ku temu jest - paradoksalnie - powiększanie procedur biurokratycznych ${ }^{8}$. Reformatorzy akademii na nowo ujawniają, że istotą neoliberalizmu jest „przeprojektowanie” nie tyle samego państwa, co instytucji publicznych, które zaczynają działać według logiki kapitali-

Studia nie są już dziśs rozumiane jako awans społeczny, a coraz częściej jako próba utrzymania statusu klasowego własnych rodziców stycznej.

Studia nie są już dziś rozumiane jako awans społeczny, a coraz częściej jako próba utrzymania statusu klasowego własnych rodziców. Widać to dobrze na przykładzie polskiej emigracji. Niechęć wykształconych do podejmowania zawodów opierających się na pracy fizycznej wynika z panującej presji społecznej. Respondenci Małgorzaty Zielińskiej odpowiadali, że na Islandii nie spotykają się z wykluczeniem i pogardą ze względu na wykonywanie pracy fizyczej. W tym miejscu ujawnia się ciekawa właściwość polskiego „społeczeństwa klasy średniej" ", a mianowicie propagowanie modelu edukacji wyższej jako potwierdzenia przynależności do klasy średniej jest formą pozytywnego odróżnienia się od klas niższych.

Biorąc pod uwagę zjawisko indywidualizacji bezrobocia, akademia jest instytucją pomnażania „kapitału ludzkiego”, czyli całości zdolności fizycznych i mentalnych, które mogą zostać wystawione na sprzedaż na rynku pracy. Krytyka dzisiejszego polskiego uniwersytetu, mającego wnosić coś do procesu indywidualnej akumulacji kapitału ludzkiego, przez władzę i media, jest w istocie próbą przerzucenia na wyższe uczelnie odpowiedzialności za poszerzające się bezrobocie wśród „niekon-

8 T. Skoczylas, Praca na uniwersytecie, [w:] Uniwersytet i emancypacja..., s. 22.

9 H. Domański, Spoteczeństwa klasy średniej, Warszawa 1994. 
kurencyjnych" absolwentów studiów każdego z trzech stopni, gdy w istocie jest ono skutkiem coraz większego stopnia prekaryzacji ogólnych stosunków pracy. Feudalny uniwersytet, który „nie przygotowuje do życia”, chce się zastąpić „wyższą szkołą zawodową”, która byłaby przyczynkiem do nadwiślańskiego kapitalizmu kognitywnego (pomysły wątpliwe zważywszy na miejsce Polski w ramach globalnego podziału $\left.\operatorname{pracy}^{10}\right)$.

\section{Exodus zamiast ucieczki}

Studia trzeciego stopnia są w Polsce coraz popularniejsze - liczba doktorantów przekroczyła w roku akademickim 2011/2012 czterdzieści tysięcy. Żadna z autorek/autorów Uniwersytetu $i$ emancypacji nie podjęła kwestii tego, na ile podjęcie tych właśnie studiów jest formą „ironicznej emancypacji”, ucieczki od rynku pracy. Rzuciłoby to nieco więcej światła na zagadnienia walki o poprawę warunków socjalnych oraz dostępu do wiedzy i jej produkcji.

Studia wszystkich trzech szczebli stają się „potencjalnym panaceum"11 na bezrobocie i pozaakademicki wyzysk pracowniczy. Potencjalnym, bo tymczasowym i defensywnym wobec permanentnych zawirowań rynkowych, do których nie sposób się przygotować. „Panaceum", bo stanowią same w sobie stosunek quasi-pracy ${ }^{12}$ wraz z niemożnością (współ)decydowania o warunkach jej wykonywania.

Defensywna walka o przywileje jest symptomatyczna dla tej ucieczki. Żądanie powrotu do starych praktyk upublicznienia uniwersytetu, zapewnienia mu autonomii względem otoczenia społecznego i rynkowego wraz ze wzrostem nakładu finansowego - to hasła anachroniczne i nieskuteczne. Podmiotem takiej zmiany nie będzie państwo, bo ono samo jest aktualnie głównym narzędziem neoliberalizacji życia społecznego. Walki gdańskich doktorantów o partycypowanie w zarządzaniu wspólnotą universitas były odważniejsze, lecz wciąż grupowały ludzi, którzy cieszą się, że nie są wyrzutkami na rynku pracy. Pominięcie tego problemu negatywnie wpływa na myślenie o bardziej ofensywnych działaniach w szerszym niż studencko-doktoranckie gronie.

10 J. Sowa, K. Szadkowski, Fabryki wiedzy, [w:] EduFactory: samoorganizacja i opór w fabrykach wiedzy, red. J. Sowa, K. Szadkowski, Kraków 2012, s. 13.

11 A. Czarnacka, Co to jest edukacja?, [w:] EduFactory..., s. 265.

12 J. Tittenbrun, Gospodarka w spoteczeństwie, Poznań 2012, s. 411. 
Konstatacja towarzysząca autorkom i redaktorkom Uniwersytetu i emancypacji dotyczy nieuchronności, w przypadku dochowania wierności „obietnicy nauk społecznych”, przyszłego starcia z kapitałem. Ucieczka od konfrontacji z kapitalistyczną logiką w okresie komercjalizacji szkolnictwa wyższego nie jest exodusem z relacji z kapitałem ${ }^{13}$, tylko „ironiczną emancypacją”.

Recenzja książki Uniwersytet i emancypacja: wiedza jako dziatanie polityczne dziatanie polityczne jako wiedza, red. M. Maciejewska, M. Trawińska, Wrocław 2012.

13 M. Hardt, A. Negri, Rzecz-pospolita: poza wtasność prywatna i dobro publiczne, tłum. Praktyka Teoretyczna, Kraków 2012, s. 255. 
BARTOSZŚLOSARSKI - student Międzyobszarowych Indywidualnych Studiów Humanistycznych i Społecznych UAM, publikował m.in. w „Le Monde diplomatique - Edycja polska” i „Bez Dogmatu”.

Dane adresowe:

Collegium Maius

ul. Fredry 10

60-568 Poznań

e-mail: b.slosarski@gmail.com

\section{Cytowanie:}

B. Ślosarski, Między exodusem a emancypacją, „Praktyka Teoretyczna” nr 1(7)/2013, http://www.praktykateoretyczna.pl/PT_nr7_2013_ NOU/20.Slosarski.pdf (dostęp dzień miesiąc rok)

Author: Bartosz Ślosarski

Title: Between Exodus and Emancipation 